Research article

\title{
MYCOBACTERIUM CELL WALL FRACTION IMMUNOSTIMULANT (AMPLIMUNETM) EFFICACY IN THE REDUCTION OF THE SEVERITY OF ETEC INDUCED DIARRHEA IN NEONATAL CALVES
}

\author{
ROMANOWSKI Radoslaw ${ }^{1}$, CULBERT Rick ${ }^{2}$, ALKEMADE Stan ${ }^{2}$, \\ MEDELLIN-PEÑA Maira J. ${ }^{2}$, BUGARSKI Dejan ${ }^{3}$, MILOVANOVIC Aleksandar ${ }^{3}$, \\ NESIC Sladjan ${ }^{4}$, MASIC Aleksandar ${ }^{2 *}$ \\ ${ }^{1}$ Vetrepharm Research Inc., London, Ontario, Canada; ${ }^{2}$ NovaVive Inc., Belleville, Ontario, Canada; \\ ${ }^{3}$ Scientific Veterinary Institute Novi Sad, Novi Sad, Serbia; ${ }^{4}$ Faculty of Veterinary Medicine, University \\ of Belgrade, Belgrade, Serbia
}

(Received 09 November 2016, Accepted 14 February 2017)

Calf diarrhea is a common disease in young animals and the primary cause of productivity and economic losses to cattle producers worldwide. According to the report from the National Animal Health Monitoring System for U.S. dairy, more than fifty percent of the deaths of un-weaned calves is attributed to severe diarrhea. Enterotoxigenic Escherichia coli (ETEC) strain K99+ remains the most common pathogen isolated from calves which are younger than three days of age. Dam vaccination and the use of antimicrobials remain the most used prophylactic and treatment options for calf diarrhea. The rise in antibiotic resistance around the world has been a major concern and new alternative therapies have been explored. Mycobacterium Cell Wall Fraction (MCWF) is a biological immunomodulator that has a potential in multiple veterinary health services such as the treatment and prevention of infectious diseases and anticancer therapy in both small and large animals. The efficacy of the MCWF in reducing the severity of neonatal calf diarrhea and its associated mortality, following challenge with ETEC $\mathrm{K} 99+$ was evaluated. Twenty-three calves were placed into two experimental groups. Eleven calves received a single $1 \mathrm{~mL}$ dose of MCWF intravenously (IV) at the onset of clinical signs of disease following challenge. Twelve non-treated, challenged calves were retained as controls. The severity and duration of diarrhea was significantly reduced in the MCWF treated group compared to untreated controls. In addition, the mortality rate in the MCWF treated group was significantly reduced to $10 \%$ while the observed mortality in the control group reached $58 \%$. Data from the current study suggest that MCWF could be used as an alternative treatment to reduce the severity, duration and mortality of ETEC induced diarrhea in neonatal calves.

Keywords: calf diarrhea, ETEC, MCWF, neonatal

Corresponding author: e-mail: aleksandar.masic@novavive.ca 


\section{INTRODUCTION}

Calf diarrhea remains the major cause of economic losses to cattle producers around the world. In the United States (US), the National Animal Health Monitoring System (NAHMS) for dairy operations USDA [1], reported that diarrhea was responsible for $57 \%$ of pre-weaned calf mortality, observed mostly in calves younger than one month of age. While the cattle industry has gone to great measures to improve herd management, animal facilities, feeding and nutrition, and the appropriate use of bio-pharmaceuticals, calf diarrhea still remains a problem due to its multifaceted nature [2]. Prevention and control strategies of diarrhea in young calves is based on a proper understanding of the disease complexities: multiple pathogens, co-infections, environmental factors, feeding and management during the calving period [3]. In cattle, due to the presence of epitheliochorial placenta [4] transplacental transfer of immunoglobulins does not occur. Therefore, the neonate is highly dependent on the passive transfer of immunoglobulins through the colostrum. The primary function of colostrum is to enhance the calf's immune system through the passive transfer of both antibody and cell-mediated immune components particularly within the first 6-18 hours of the calf's life [5]. Failure to obtain colostrum predisposes the neonate to the development of disease [6]. It has been documented that Escherichia coli, although part of the normal microbiota of the gastrointestinal tract (GIT), can also be associated with a variety of pathological conditions in newborn calves [7]. Enterotoxigenic E. coli (ETEC) possessing the F5 (K99) fimbrial adhesin [8] and producing heat-stable enterotoxin [9], is the most common pathogen causing moderate to severe diarrhea and mortality in one to three days old calves. In addition, other enteropathogens known as a common cause of diarrhea in calves under one month of age are Coronavirus, Cryptosporidium parvum, Rotavirus and Clostridium perfringens [10-12].

Current preventive strategies for neonatal diarrhea in calves include the metaphylactic use of antibiotics, anti-E. coli monoclonal antibodies enriched colostrum and fluid therapies. Commercial multivalent vaccines are available for use in healthy pregnant heifers and cows as an aid in the prevention of neonatal calf diarrhea [13,14]. These vaccines stimulate the production of protective antibodies that are present in the dam's colostrum; however, the disadvantage of this approach is that due to variations in farm management not all calves receive a sufficient quantity of colostrum, or any at all particularly in the veal industry. The main disadvantage for the use of antibiotics as a preventive and uncontrolled treatment measure is the increasing concern for antibiotic resistance, which could potentially lead to the development of novel pathogenic strains that may have a significant negative impact on both animal and human health. Therefore, the focus of current research in the field of large animal veterinary science is on the development of novel natural and biologically related products, such as immune response modifiers [immunomodulators] which could significantly improve the health status of animals and reduce the need for antibiotic use $[15,16]$. The Mycobacterium Cell Wall Fraction (MCWF) is a biological immunomodulator derived from nonpathogenic Mycobacterium phlei. MCWF has potential use in multiple veterinary health services, such as the treatment of infectious diseases [17] and in anticancer therapy 
[18]. The mode of action of MCWF is based on the activation of innate and adaptive (humoral and cell-mediated) immunity with the purpose of recognition, reaction to and recovery from infections. In the current study, we demonstrated the efficacy of the commercially available formulation MCWF (Amplimune ${ }^{\mathrm{TM}}$, NovaVive Inc., Belleville, Ontario, Canada) as an immunostimulant to reduce the severity of diarrhea and its associated mortality in neonatal calves infected with ETEC K99+.

\section{MATERIALS AND METHODS}

\section{Description of test animals}

Twenty-three, newborn, clinically healthy, male, colostrum-deprived Holstein calves were purchased from multiple local dairy farms within four hours of birth and transported to the Bioniche research facility at Putnam, Ontario, Canada. On arrival at the research farm, a whole blood sample was collected from each calf and the zinc sulphate turbidity test (ZST) was performed (on arrival and 48 hours later) to confirm that a transfer of maternal antibodies had not occurred. Each calf was identified with an all-flex ear tag marked with a unique identification number. The same identification number was assigned to the corresponding blood and serum samples. Calves were housed in individual pens bedded with straw, within an open shelter that prevented direct contact with other animals. Each pen was cleaned daily and disinfected between calves. Calves were fed three times daily with a milk replacer. No other medications or vaccinations, except for the tested product, were administered throughout the study period.

\section{Mycobacterium cell wall fraction (MCWF) immunostimulant}

Mycobacterium Cell Wall Fraction Immunostimulant (Serial Number 910707A) was manufactured according to the current outline of production filed with the USDA as product code 9300.02 . The trade name of this product, currently registered in the USA and Canada, is Amplimune $\mathrm{T}^{\mathrm{TM}}$ and contains purified MCWF, and squalane emulsified in phosphate-buffered saline (PBS) solution.. Amplimune ${ }^{\mathrm{TM}}$, is manufactured at NovaVive USA Inc., Athens, Georgia, U.S.A. The recommended label dose of $1 \mathrm{~mL}$ intravenously was used in the current study.

\section{Experimental design}

The study was randomized, controlled and blinded. The veterinary technician administering the MCWF treatment was not involved in data collection. A designated veterinarian performing clinical scoring and data collection was blinded to the experimental groups. The principal investigator and personnel performing laboratory testing and statistical analysis were also blinded to the experimental groups. All procedures were designed in accordance with the Canadian Council on Animal Care (CCAC) guidelines. The test facility was a registered research facility under the Animals for Research Act, Ontario Ministry of Agriculture and Food and was also accredited in Good Animal Practices by the CCAC. In order to ensure compliance, the study 
protocol (AUP\# 0401-1979) was reviewed and approved by the test facility's Animal Care Committee before the start of the trial. Twenty-three calves were used for the purpose of the study and placed into two experimental groups. A random allocation chart was prepared in advance using the random function in Excel statistical software (Microsoft, CA, USA) to determine which group each calf was assigned to. The designated treatment injection site was the jugular vein on the left side of the neck. All blood samples were collected from the right jugular vein to ensure that any reactions at the site of injection were specific to MCWF. Eleven calves were assigned to group 1 and received a single $1 \mathrm{~mL}$ dose of MCWF intravenously (IV) at the onset of clinical signs of disease (diarrhea) following challenge. Following challenge and disease onset, calves were not treated with antibiotics. Calves were observed for seven days following challenge. One calf from the MCWF group was removed from the study, at 36 hours after birth, due to an umbilical cord infection and the collected data were not analyzed.

\section{Challenge culture and treatment procedure}

The ETEC culture was obtained from Dr. David Francis, South Dakota State Veterinary Diagnostic Laboratory, Brookings, SD. After confirmation of its purity and the presence of K99 pili, the culture was expanded and lyophilized. A fresh challenge culture was started every eight hours during the calf challenge period by growing the bacteria for 12 hours at $37^{\circ} \mathrm{C}$ in Minca broth in a shake flask. Only fresh cultures less than 12 hours old were used to challenge the calves. The culture was diluted to a standardized optical density (OD) of 0.2 just prior to challenge. Viable counts of each challenge dose were performed to confirm the number of pathogenic microorganisms. The target challenge dose was $2 \times 10^{9}$ colony forming units (CFU). Each calf was administered an oral dose of $20 \mathrm{~mL}$ of challenge culture containing $2 \mathrm{x}$ $10^{9} \mathrm{CFU}$ diluted in $250 \mathrm{~mL}$ of milk replacer. The average age of the calves at the time of challenge was 5.6 and 7.8 hours for the control and MCWF groups, respectively. Ten calves in group 1 were treated with one IV dose $(1 \mathrm{~mL})$ of MCWF product when the first clinical signs of diarrhea were observed (18-24 hours post challenge). Following MCWF administration, the calves were closely monitored two hours for the occurrence of any systemic or local adverse reactions. A fecal sample from each calf was collected at the onset of clinical signs and subjected to microbiological confirmatory testing for the presence of E.coli K99+.

\section{Clinical observations}

Each calf's vital signs were recorded immediately upon arrival at the research facility and prior to challenge by the designated clinical veterinarian. Following challenge, and during the seven-day course of the study, each calf was further monitored three times per day at feeding times and records of body temperature, fecal consistency, behavior, milk consumption, hydration and body weight were collected. Clinical scores for behavior, milk consumption, and fecal consistency were scored on a scale of 0 (normal) to 3 (severe symptoms) and dehydration was scored on a scale of 0 (normal) to 2 (severe dehydration) (Table 1). Calves were weighed on arrival, prior to each 


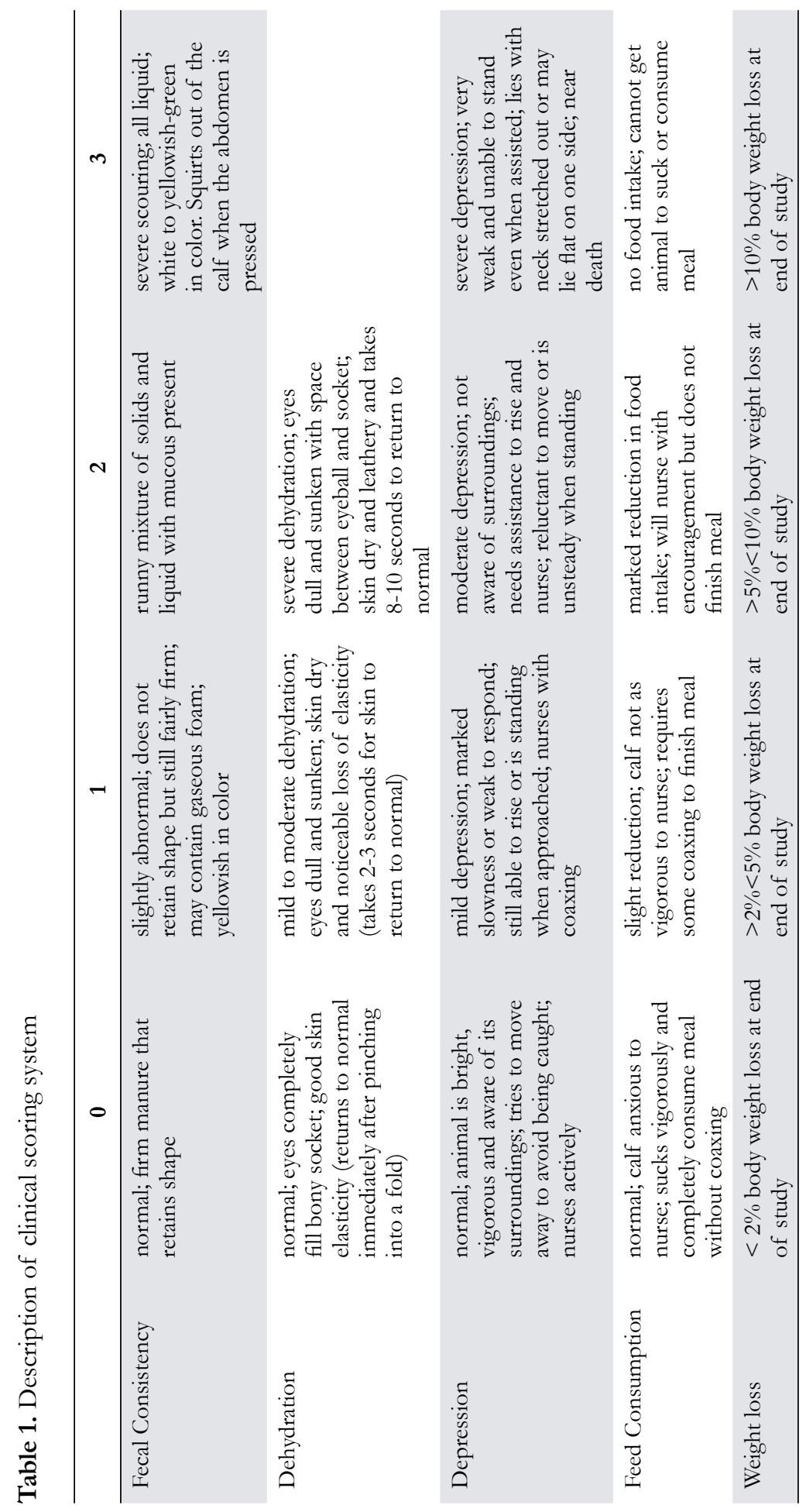


morning feeding and at the time of death or euthanasia and body scores were assigned daily according to the total body weight loss (Table 1). The injection site was shaved in both groups to maintain the blind status and observed daily for any signs of swelling, induration or pain.

Due to the animal welfare considerations and as per guidance from United States Department of Agriculture (1) and Canadian Food Inspection Agency (CFIA) the supportive I.V fluid therapy was applied (Calf-lyte) when a combination of dehydration score of 2 and fecal and behavior score of 3 were observed. If same clinical scores were observed for two consecutive days animals were humanely euthanized by intravenous administration of barbiturate $(80 \mathrm{mg} / \mathrm{kg}$ sodium pentobarbital). Any calf that died during the course of the study was necropsied and fecal samples were collected and cultured to confirm the presence of the challenge microorganism (ETEC K99 $)$. Small intestines, jejunum and ileum were removed and sent to the Pathobiology Department at Ontario Veterinary College, University of Guelph for examination.

\section{Statistical analysis}

Fisher's Exact Probability statistical test was used to determine the significance of mortality data. The One-way ANOVA analysis of variance was used to determine the statistical significance of the clinical scores (diarrhea, behavior, milk consumption, duration and mortality) between the two groups. GraphPad Prism 6 statistical software (Santa Cruz, CA, USA) was used for all statistical analysis.

\section{RESULTS}

\section{Adverse reactions}

Following challenge with ETEC $\mathrm{K}^{+} 9^{+}$and treatment with MCWF, calves were monitored closely for two hours for any occurrence of systemic or local reactions. Observations continued on a daily basis, three times a day for the entire duration of the study (seven days). There were no untoward reactions observed in any of the calves given MCWF (data not shown).

\section{Clinical observations}

The zinc turbidity test (ZST) was performed twice (on arrival and 48h later) to determine if passive transfer of colostral IgG antibodies occurred. All calves tested negative for the presence of colostral $\operatorname{Ig} G$ antibodies at each test point (data not shown).

All calves were deemed healthy upon arrival as determined by physical examination. Eighteen to twenty-four hours post challenge with ETEC $\mathrm{K}^{+} 9^{+}$, profuse watery to pasty, pale yellow to white, foul-smelling diarrhea, occasionally streaked with blood 
flecks, was observed in all challenged calves. Defecation was frequent and effortless and the tail and perineum were soiled with faeces.

\section{Faeces consistency and duration of diarrhea}

Pens were cleaned daily and faeces consistency was scored on three occasions within the 24-hour period (morning, afternoon and evening). Faeces was scored on day 0, prior challenge, and then daily for the duration of the study. First signs of diarrhea occurred 18-24h (median of $18 \mathrm{~h}$ ) following challenge in all calves. Severity and duration of diarrhea was significantly reduced in the MCWF immunostimulant treated group compared to controls (Figure 1). Clinical scores related to faeces consistency were statistically significant $(\mathrm{p}=0.03)$ between the two groups with mean faecal scores of 1.4 and 1.95 (Figure 1A) for MCWF and control group respectively. Furthermore, the mean duration of diarrhea in untreated calves was 5.6 days compared to 4.3 days in MCWF group (Figure 1B). For the purpose of data analysis on the duration of diarrhea in challenged calves only results from surviving animals were taken into consideration. Even though there was no statistically significant difference in the duration of diarrhea between the two groups, there was an obvious biological and clinical difference in favor of the MCWF group (duration of diarrhea reduced by 1.3 days).

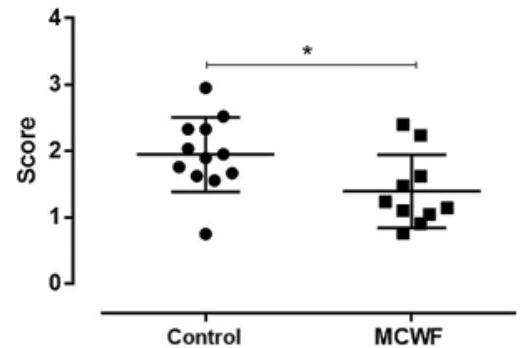

a

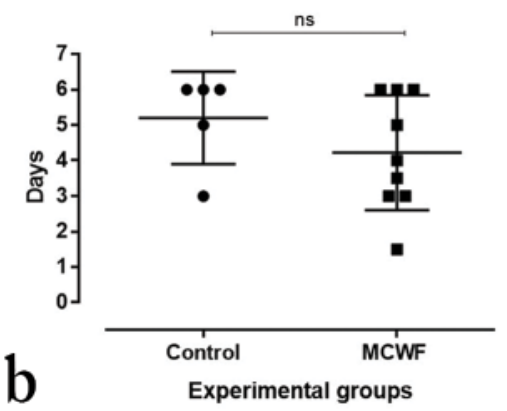

Figure 1. Faecal consistency scores and mean duration of diarrhea; a) Mean clinical scores for faecal consistency between the two groups (MCWF and control; $\left.{ }^{*} \mathrm{p}=0.03\right)$; b) Mean clinical scores for duration of diarrhea in calves between the two groups (MCWF and control; not statistically significant (ns))

\section{Hydration and behavior}

Consistent with previous observation on E. coli $\mathrm{K}^{+} 9^{+}$induced diarrhea in neonatal calves, animals in the control group had a significantly higher dehydration mean clinical score of 0.2 versus $0.04(\mathrm{p}=0.04)$ in the MCWF treated group (Figure 2A). Furthermore, mean behavioral (depression) scores were also reduced ( 0.46 versus 0.6$)$ in the MCWF treated calves when compared to controls respectively; (Figure 2B). 

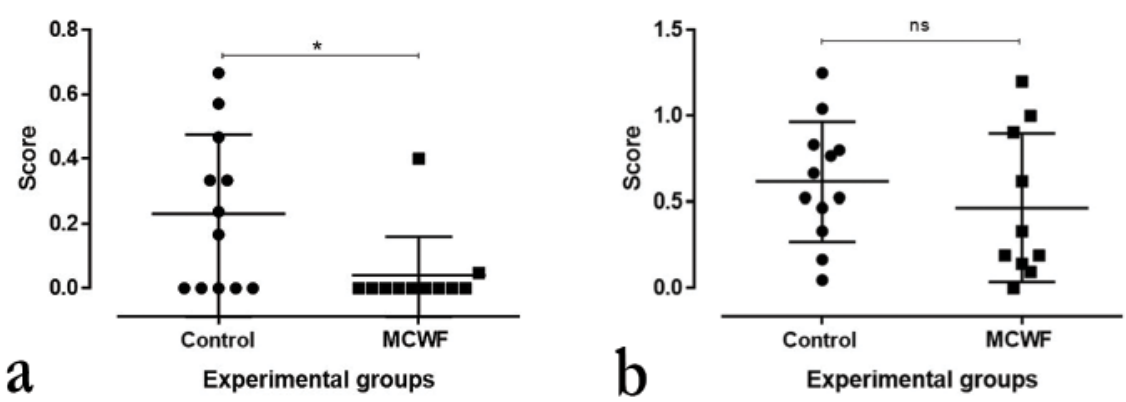

Figure 2. Mean clinical scores for dehydration and behaviour; a) Mean clinical scores for dehydration between the two groups (MCWF and control; $\left.{ }^{*} \mathrm{p}=0.04\right)$; b) Mean clinical scores for behaviour of calves between the two groups (MCWF and control; not statistically significant (ns)).

\section{Milk consumption and body weights}

Milk consumption and body weights observations correlated with the course and pathogenesis characteristic of E. coli infection in neonatal calves. Mean starting body weights for animals in both experimental groups were not significantly different (Figure 3A). Animals in both experimental groups showed considerate body weight loss during the study (Figure 3A). Mean clinical body scores related to weight loss (Figure 3B) were lower in the MCWF group (mean score of 1.2 ) compared to the control group (mean score of 2). MCWF treated animals lost on average 4.2\% (1.7 kg)
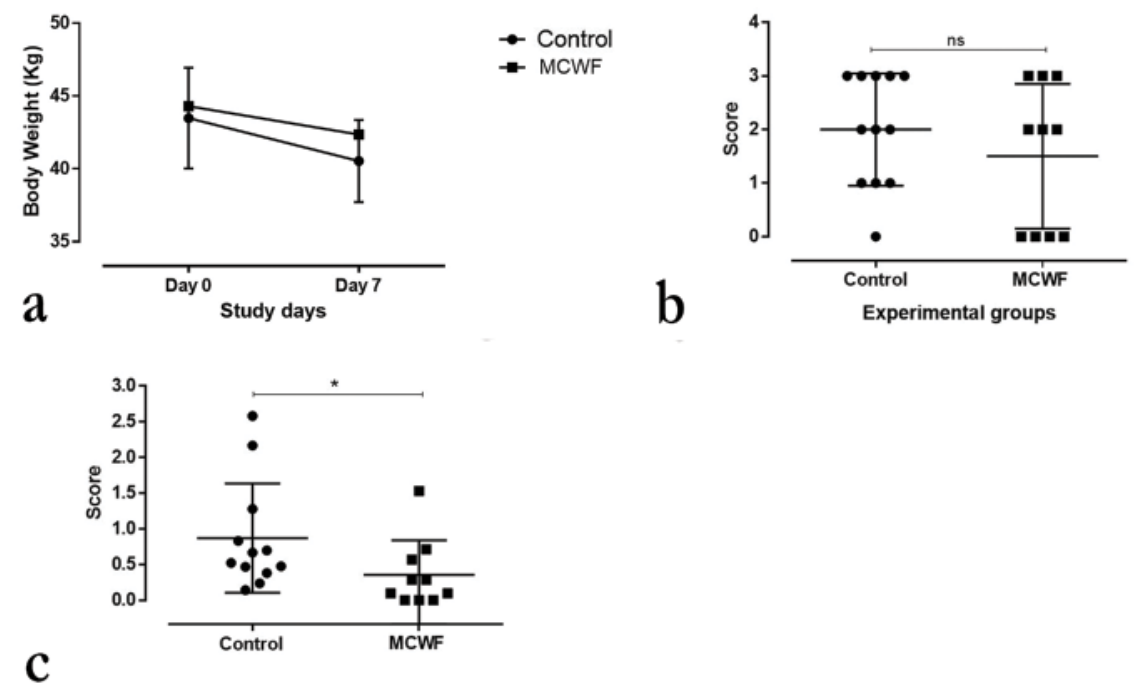

Figure 3. Mean scores for milk intake, body scores and body weights; a) Differences in body weights between the two groups (MCWF and control during the study; not statistically significant (ns)); b) Mean body scores of calves between the two groups (MCWF and control; not statistically significant (ns)); c) Mean clinical scores related to milk intake between the two groups (MCWF and control; $\left.{ }^{*} \mathrm{p}=0.02\right)$ 
of their starting body weight while animals in the control group lost $6.9 \%(2.95 \mathrm{~kg})$ of their starting body weight (Figure 3A). Four out of ten animals in the MCWF group did not show any signs of weight loss and had an average increase of $4.25 \%$ body weight at day seven compared to the control group in which only one animal showed increased body weight. Milk consumption results were in correlation with previous observations, where a lower milk intake was observed in the MCWF treated group $(p=0.02)$ when compared to the control group (Figure 3B).

\section{Body temperatures}

Body temperatures were recorded upon arrival, prior to challenge and then during each scheduled daily observation. Slightly elevated body temperatures were observed at 12 hours following challenge in all animals, but quickly returned to normal within 24 hours post-challenge. Body temperatures in the control group dropped below the normal value while no significant changes in the MCWF group were observed (Figure 4).

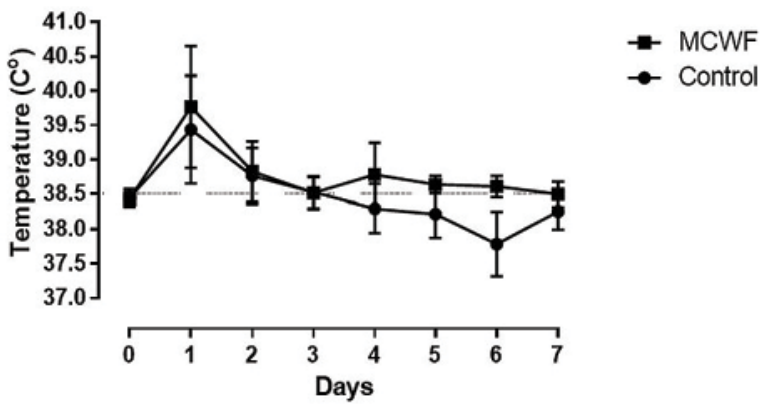

Figure 4. Body temperatures; Mean body temperatures of calves in two groups (MCWF and control) during the course of the study (seven days). Not statistically significant (ns).

\section{Survival}

To determine the survival rate following ETEC challenge, animals were monitored for a minimum of seven days. As shown in Figure 5, the survival rate in the MCWF group was $90 \%$ (1 dead out of 10 animals), while survival rate in the control group was $42 \%$ (7 died out of 12 animals), which was statistically significant at a 95\% confidence level $(\mathrm{p}<0.01)$. The average time of death in the control group was 69.8 hours following challenge with the earliest occurrences at approximately 36-40 hours (3 deaths). One animal in the MCWF group died at 98 hours following challenge. Two animals from the control group were humanely euthanized as per protocol and CCAC guidance due to severe dehydration, diarrhea and decreased attitude. 


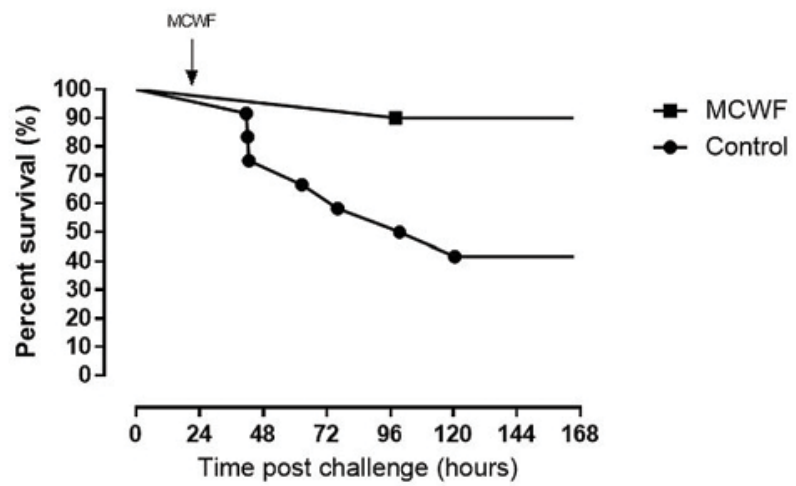

Figure 5. Survival rate; Survival rate in neonatal calves between the two groups during the course of the study $\left(\mathrm{MCWF}=90 \%\right.$ and control $=42 \%$; $\left.{ }^{*} \mathrm{p}<0.01\right)$ with the time of death in both groups

\section{Necropsy and bacterial culture}

Consistent with previous observations related to infections of neonatal calves with ETEC $\mathrm{K} 9^{+}[19,20]$, the most dominant gross finding at necropsy was a mild to moderate catarrhal enteritis in the small intestines (ileum and jejunum). Dehydration of carcasses and a white-yellowish fluid in the intestines and smaller amounts of undigested milk were observed, as well. No other gross pathological findings were found. On histopathology, a mild neutrophil infiltration into the lamina propria and between the base of the villi was found. Villi maintained their shape without signs of atrophy, crypts were sorted properly and the surface epithelium was normal (Figure 6). These findings were consistent with microscopic changes characteristic for enterotoxigenic colibacillosis $[19,20]$.

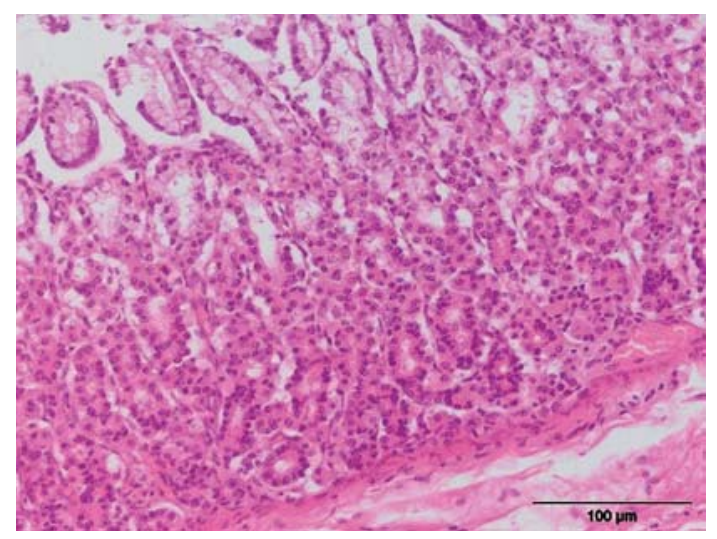

Figure 6. Histopathology of the small intestine; Hematoxylin-Eosin (HE) staining of the representative sample of small intestine (ileum) from one four-day old calf that died due following ETEC K99+ infection. Magnification 400x, scale bar at $100 \mu \mathrm{m}$. 


\section{DISCUSSION}

Neonatal calves are most susceptible to infection in the first few hours of life [2]. The pathogens most commonly incriminated in neonatal enteric infections include viral (Rotavirus and Coronavirus), protozoal (Cryptosporidium parvum) and bacterial pathogens (enterotoxigenic Escherichia coli ${\mathrm{K} 99^{+}}^{+}$and Salmonella spp.) [10,21,22]. Calf diarrhea induced by ETEC producing the $\mathrm{K} 9^{+}$adhesion antigen is still the most common microorganism isolated from diarrheic calves within the first three days of life $[20,23]$. The heat-stable enterotoxin produced by ETEC K99+ alters the functions of the enterocytes by increasing secretion and reducing absorption of water, stimulating the release of excessive liquid leading to the development of a secretory (watery) diarrhea [19]. Consequently, depression, rapid weight loss, increased milk intake and mild to moderate mortality rate are observed causing significant economic losses to the producers. Economic implications associated with ETEC diarrhea include increased investment and lower profits due to lower daily weight gains, increased costs of treatment and higher numbers of underweight or dead animals [20-22]. Cattle producers, particularly within the veal and beef calf industry are increasingly concerned with the high morbidity percentage and mortality among male calves which are removed from their dams within hours following birth. These calves receive no or minimal colostrum, and are exposed to significant levels of stress, including being shipped to auction barns or directly to veal operations. In most instances, these calves arrive at their final destinations in poor health, already infected with one or multiple pathogens and without any supportive therapy. These calves have a difficult time adjusting to the new environment and usually show clinical signs of enteric and/or respiratory diseases. In addition, they have difficulties entering the regular production process, resulting in the immediate application of supportive and metaphylactic treatments and added production costs.

In this study, we aimed to mimic real-time conditions in terms of early management of newborn male calves and early exposure to one of the most common pathogens, while testing an alternative to antibiotic therapy. The established challenge model was successful and consistent with ETEC pathogenesis and clinical symptoms in terms of diarrhea onset, body temperatures, changes of attitude and milk consumption as described previously [20,23]. In addition, pathomorphological observations on post mortem examination were consistent with ETEC infection described as mild to moderate dehydration and enterotoxicaemia contributing to a moderate mortality rate $[19,20]$. The study results clearly demonstrated beneficial effect of MCWF administration in colostrum deprived one to two day old calves challenged with ETEC K99+ as demonstrated by a reduced severity and duration of diarrhea, reduced dehydration, lower behavior and food intake scores. Furthermore, animals in the MCWF group had a significantly reduced loss of body weight compared to the untreated controls with 4 animals in this group gaining up to $4 \%$ of body weight since the start of the study and pre-challenge. 
Preventive and treatment measures to reduce the morbidity and mortality associated with neonatal diarrhea include metaphylaxis with a variety of antibiotics, combinations of antibiotics and fluids. However, the use of antibiotics maybe costly and not applicable in all cow-calf operations, particularly in organic certified operations. The main disadvantage of antibiotic therapy is its relationship to bacterial resistance and consequently increased health concern for both humans and animals.

Compounds capable to elicit the immune response in the host, to either upregulate or downregulate specific events, are classified as immunomodulators. MCWF contain immunomodulatory compounds such as trehalose 6,6'-dimycolate (TDM) and muramyl dipeptide (MDP) [24]. MDP enhances the expression of surface markers on microorganisms that are necessary for cell adhesion and antigen presentation. This enhancement allows for an increase in phagocytosis, antimicrobial activity and antibody-mediated cytotoxicity [25-27]. Moreover, MDP has been shown to induce immune responses by increasing interferon gamma (IFN- $\gamma$ ) and other cytokine production and stimulating the production of lymphocytes [28-30]. The TDM is a glycolipid component of the mycobacterial cell wall that is found to be a nonspecific immunotherapeutic agent against cancer and infectious diseases [31]. TDM was also shown to stimulate macrophage activity [32] and enhance the production of interleukin 6 (IL-6) [33]. It is proposed that MCWF targets the calf's innate immune and cell-mediated immune responses in a similar manner, thus providing increased resistance to early infection and reduction of associated clinical signs. MCWF has the ability to attract macrophages, neutrophils and initiate cytokine production in neonatal calves following intravenous, subcutaneous and intramuscular administration [34]. Data suggested that single MCWF administration, even in the high presence of cortisol, is sufficient to trigger a strong innate and cell-mediated immune response as measured by IFN- $\gamma$, IL-2 and neutrophil influx and activation of naive CD4+ and CD8+ cells [34]. These data, accompanied with the current findings on increased survival rate, reduced diarrhea and other clinical signs following challenge with ETEC $\mathrm{K} 9^{+}$provide sufficient evidence that MCWF can be used as a novel therapeutic for ETEC treatment and potential antibiotic alternative. Furthermore, our data suggested that if MCWF is administered early in infection it can prevent or reduce economic losses due to increased food consumption, and less underweight or dead animals. In addition, early activation of the neonate's immune system could overcome the effects of early infection and stress commonly seen in veal and baby beef animals across North America. The use of MCWF could provide a significant health and cost benefit to the farm management, particularly to organic farming operations where the use of antibiotics is prohibited. Additional studies are underway to explore further MCWF applications and application protocols, in order to improve the health status of both cows and calves in small and large dairy and beef operations. 


\section{Authors' contributions}

PM, NS, BD and MA were responsible for assisting with manuscript drafting, validation of the study results and statistics, and justification of the references. CR participated in the study design and was responsible for obtaining the animals, administering the test product(s), study monitoring and final reports. RR participated in the study design and was responsible all veterinary observations and evaluations of the animals, and the collection and evaluation of clinical pathology samples. AS and MA were responsible for the overall study, participated in the study design and performed the statistical analyses, statistical reports and wrote the manuscript. All authors read and approved the final manuscript.

\section{Declaration of conflicting interests}

The author(s) declared no potential conflicts of interest with respect to the research, authorship, and/or publication of this article.

\section{REFERENCES}

1. USDA. Part 1: Reference of Dairy Cattle health and Management Practices in the United States, October 2007 ed, 1-122. USDA-APHIS.

2. Scott PR, Hall GA, Jones PW, Morgan JH. 2004. Calf diarrhoea., 185-214. In A.H. A (ed), Bovine Medicine Disease and Husbandry of Cattle, Second Edition ed. Blackwell Science.

3. Cho Y, Yoon J., An overview of calf diarrhea - infectious etiology, diagnosis, and intervention. J Vet Sci 2014, 15:1-17.

4. Weaver DM, Tyler JW, VanMetre DC, Hostetler DE, Barrington GM, Passive Transfer of Colostral Immunoglobulins in Calves. J Vet Intern Med 2000, 14:569-577.

5. Larson RL, Tyler JW, Schultz LG, Tessman RK, Hostetler DE, Management strategies to decrease calf death losses in beef herds. JAVMA 2004, 224:34-99.

6. Barrington GM, Gay JM, Evermann JF, 2002. Biosecurity for neonatal gastrointestinal diseases. The Veterinary Clinicls, Food Animal Practice 2002, 18:7-34.

7. Acres SD, Enterotoxigenic Escherichia coli Infections in Newborn Calves: A Review. J Dairy Sci 1985, 68:229-256.

8. Nagy B, Fekete PZ, Enterotoxigenic Escherichia coli in veterinary medicine. Int J Med Microbiol 2005, 295:443-454.

9. Forte LR, Thorne PK, Eber SL, Krause WJ, Freeman RH, Francis SH, Corbin JD, Stimulation of intestinal Cl- transport by heat-stable enterotoxin: activation of cAMPdependent protein kinase by cGMP. Am J Physiology 1992, 263:607-615.

10. Garcia A, Ruiz-Santa-Quiteria JA, Orden JA, Cid D, Sanz R, Gomez-Bautista M, De La Fuente R, Rotavirus and concurrent infections with other enteropathogens in neonatal diarrheic calves in Spain. Comp Immunol Microbiol Infect Dis 2000, 23:175-183.

11. Uhde FL, Kaufmann H, Sager H, Albini S, Zanoni R, Schelling E, Meylan M, Prevalence of four enteropathogens in the faeces of young diarrhoeic dairy calves in Switzerland. Vet Rec 2008, 163:362-366. 
12. Izzo MM, Kirkland PD, Mohler VL, Perkins NR, Gunn AA, House JK, Prevalence of major enteric pathogens in Australian dairy calves with diarrhoea. Aust Vet J 2011, 89:167173.

13. Moon HW, Bunn TO, Vaccines for preventing enterotoxigenic Escherichia coli infections in farm animals. Vaccine 1993, 11:213-220.

14. Baumann LE, Cattle Vaccines: Recommendations and Available Products 2004. Revision 2004):1-20.

15. Kimura K, Goff JP, Canning P, Wang C, Roth JA, Effect of recombinant bovine granulocyte colony-stimulating factor covalently bound to polyethylene glycol injection on neutrophil number and function in periparturient dairy cows. J Dairy Sci 2014, 97:4842-4851.

16. LLC BAHC. 2015. Zelnate ${ }^{\circledR}$ DNA Immunostimulant: a new chapter in BRD management. Bayer HealthCare LLC, Animal Health, Shawnee Mission, Kansas 66201,

17. D. Rogan EF, E. Rodr1'guez, J. Wade,S.F. Sa'nchez Bruni, Use of a Mycobacterial Cell Wall Extract (MCWE) in Susceptible Mares to Clear Experimentally Induced Endometritis With Streptococcus zooepidemicus. J Equine Vet Sci 2007, 27:112-117.

18. Filion MC, Phillips NC, Therapeutic potential of mycobacterial cell wall-DNA complexes. Expert Opin Investig Drugs 2001, 10:2157-2165.

19. McNamara BP, Koutsouris A, O’Connell CB, Nougayre'de JP, Donnenberg MS, Hecht G, Molecular Dissection of the mechanisms through which enteropathogenic Escherichia coli Gastroenterology 2001, 121:496-497.

20. Gyles CL, Fairbrother JM, Escherichia coli, 193-223. In al GCe (ed), Pathogenesis of Bacterial Infections in Animals, Third Edition ed. Blackwell, Ames, Iowa 2004.

21. De la Fuente R, Garcia JA, Ruiz-Santa-Quiteira JA, Luzon M, Cid D, Garcia S, Orden JA, Gomez-Bautista M, Proportional morbidity rates of enteropathogens among diarrheic dairy calves in central Spain. Prev Vet Med 1998, 36(2):145-52.

22. Waltner-Toews D, Martin SW, Meek AH, An epidemiological study of selected calf pathogens on Holstein dairy farms in south-western Ontario. Can J Vet Res 1986, 50:307313.

23. Foster DM, Smith GW, Pathophysiology of Diarrhea in Calves. Vet Clin Food Anim 2009, 25:13-36.

24. Le Garrec Y, Immunomodifiers of bacteria. Comp Immunol Microbiol Infect Dis 1986, 9:137-141.

25. O’Reilly T, Zak O, Enhancement of the Effectiveness of Antimicrobial Therapy by Muramyl Peptide Immunomodulators. Clin Infect Dis 1992, 14:1100-1109.

26. Darcissac EC, Bahr GM, Parant MA, Chedid LA, Riveau GJ, Selective induction of CD11a,b,c/CD18 and CD54 expression at the cell surface of human leukocytes by muramyl peptides. Cell Immunol 1996, 169.

27. Heinzelmann M, Polk HCJ, Chernobelsky A, Stites TP, Gordon LE, Endotoxin and muramyl dipeptide modulate surface receptor expression on human mononuclear cells. Immunopathology 2000, 48:117-128.

28. Saiki I, Fidler IJ, Synergistic activation by recombinant mouse interferon-gamma and muramyl dipeptide of tumoricidal properties in mouse macrophages. J Immunol 1985, 135:684-688.

29. Souvannavong V, Brown S, Adam A, Muramyl dipeptide (MDP) synergizes with interleukin 2 and interleukin 4 to stimulate, respectively, the differentiation and proliferation of $\mathrm{B}$ cells. Cell Immunol 1990, 126:106-116. 
30. Traub S, von Aulock S, Hartung T, Hermann C, MDP and other muropeptides - direct and synergistic effects on the immune system. J Endotoxin Res 2006, 12:69-85.

31. Azuma I, Synthetic immunoadjuvants: application to non-specific host stimulation and potentiation of vaccine immunogenicity. Vaccine 1992, 10:1000-1006.

32. Madonna GS, Ledney GD, Elliott TB, Brook I, Ulrich JT, Meyers KR, Patchen ML, Walker RI, Trehalose dimycolate enhances resistance to infection in neutropenic animals. . Infect Immun 1989, 57:2495-2501.

33. Nishizawa M, Yamamoto H, Imagawa H, Barbier-Chassefiere V, Petit E, Azuma I, PapyGarcia D, Efficient syntheses of a series of trehalose dimycolate (TDM)/trehalose dicorynomycolate (TDCM) analogues and their interleukin-6 level enhancement activity in mice sera. J Organic Chemistry 2007, 72:1627-1633.

34. Griebel P, Evaluation of the ability of Mycobacterium cell wall fraction (MCW) immunostimulant to alter blood leukocyte populations in newborn calves. Vaccine and Infectious Disease organizaton (VIDO) 1999, Inc N, NovaViveInc webpage.

\title{
EFIKASNOST IMUNOSTIMULANTA (AMPLIMUNETM) POREKLOM OD FRAKCIJA MIKOBAKTERIJSKOG ĆELIJSKOG ZIDA U SMANJENJU INTENZITETA DIJAREJE NEONATALNE TELADI IZAZVANE SA ENTEROTOKSIČNOM Escherichia coli (ETEC)
}

\author{
ROMANOWSKI Radoslaw, CULBERT Rick, ALKEMADE Stan, \\ MEDELLIN-PEÑA Maira J., BUGARSKI Dejan, MILOVANOVIC Aleksandar, \\ NESIC Sladjan, MASIC Aleksandar
}

Dijareja teladi je uobičajena bolest kod mladih životinja i primarni uzrok pada produktivnosti i ekonomskih gubitaka u govedarskoj industriji širom sveta. Prema izveštaju National Animal Health Monitoring System Američke agencije za mleko, više od pedeset procenata uginuća nezalučene teladi pripisuje se teškim prolivima. Enterotoksična Escherichia coli (ETEC) soj K99+ još uvek je najčešći patogen izolovan od teladi mlađih od tri dana starosti. Vakcinacija krava i upotreba antibiotika se i dalje najviše koriste kao metode prevencije i terapije dijareje teladi. Porast rezistencije mikroorganizama na antibiotike predstavlja i dalje veliku opasnost širom sveta što je i dovelo do razvoja istraživanja alternativnih terapija. Frakcije ćelijskog zida mikobakterija (MCWF) su biološki imunomodulator koji ima potencijal za upotrebu u više veterinarskih zdrastvenih usluga kao što je lečenje i prevencija zaraznih bolesti i u onkologiji malih i velikh životinja. Efikasnost MCWF u smanjenju mortaliteta povezanih sa neonatalnom dijarejom teladi nakon ekperimentalne infekcije sa sojem ETEC K99+ je istraživan u ovom radu. Dvadeset i tri teleta su bila podeljena u dve eksperimentalne grupe. Jedanaest teladi je primilo jednu dozu MCWF od $1 \mathrm{~mL}$ intravenski (IV) na početku pojave prvih 
kliničkih znakova bolesti nakon infekcije. Dvanaest netretiranih, inficiranih teladi su korišćeni kao kontrolna grupa. Intenzitet i trajanje dijareje su bili značajno smanjeni u grupi teladi tretiranih sa MCWF nakon poređenja sa ne tretiranom kontrolnom grupom. Osim toga, smrtnost u MCWF tretiranoj grupi značajno je smanjena na 10\%, dok je smrtnost u kontrolnoj grupi iznosila 58\%. Podaci iz prikazanog ogleda ukazuju na to da se MCWF može koristiti kao alternativni tretman za smanjenje jačine, trajanja infekcije i mortaliteta neonatalne teladi sa dijarejom, uzrokovanom ETEC. 